\title{
Classical and Christian Auctoritas in Marsilio Ficino's preface to the Corpus Hermeticum
}

\author{
Iskander I. Rocha Parker \\ and György E. Szönyi
}

\section{INTRODUCTION}

Learning Greek was a key factor for the philosophical and literary development of the humanist intellectuals of the Renaissance. It provided humanists such as Marsilio Ficino with the possibility of accessing texts that had not been read in the West for hundreds of years. One of those texts was the Corpus Hermeticum, a collection of texts attributed to Hermes Trismegistus. In the preface to his translation of the Corpus Hermeticum into Latin, Ficino explains the content of the work and its importance for understanding the wisdom given by God. This provides insight into Ficino's understanding of antiquity, especially of Greco-Roman conceptions influential in fifteenth-century humanist circles.

Ficino was a physician, theologian, philosopher, teacher, and translator active from 1457 to 1498 . He learned Greek from Platina at the age of twenty-six, which allowed him to begin his career as a translator, as Giovanni Corsi describes in his Life of Marsilio Ficino. Ficino's intellectual skills and potential came to the notice of Cosimo de Medici, ${ }^{1}$ who supported his studies in Greek. Cosimo not only supported Ficino financially but also provided him lodging in

* Colegio Chimalistac, Arenal 36, 01050 Ciudad de México, Mexico; iskanderparker@gmail.com.

** Department of Medieval Studies, Central European University, Quellenstraße 51, A-110o Wien, Austria; SzonyiGy@ceu.edu.

1 Corsi, "The Life of Marsilio Ficino," 5. 
the Villa Careggi for doing his translation work. Cosimo aimed to have the Corpus Hermeticum translated into Latin, ${ }^{2}$ along with the remainder of the Platonic corpus.

Cosimo's interest in the Corpus Hermeticum was likely owed to his encounters with Gemistos Plethon ${ }^{3}$ during the Council of Ferrara-Florence between 1431 and 1449. The council had been moved to Florence thanks to Cosimo's diplomatic abilities and due to the threat of the plague. ${ }^{4}$ Cosimo was inspired by Plethon to develop an academia in Florence, ${ }^{5}$ and the institution had Ficino as the head. ${ }^{6}$ The Council of Ferrara-Florence promoted Byzantine scholars' transfer to Italy while Constantinople was under the menace of Mehmet II, resulting in a flood of intellectuals from the Byzantine Empire and a reintroduction in the West of the necessary knowledge for the translation and understanding of Greek texts such as the Corpus Hermeticum.

The development of the ideas of 15 th-century humanists owed much to the new translations from Greek. Like other humanists of his time, Marsilio Ficino was deeply influenced by Platonic and Neoplatonic philosophy. Among the subjects that he sought to understand were the origins of knowledge and wisdom. His explanation mixed the Greco-Roman and Christian frameworks, invoking big names to support his arguments. Quintilian had given this rhetorical device the name auctoritas in his Institutio Oratoria:

Nam sententiis quidem poetarum non orationes modo sunt refertae sed libri etiam philosophorum, qui quanquam inferiora omnia praeceptis suis ac litteris credunt, repetere tamen auctoritatem a plurimis versibus non fastidierunt. Neque est ignobile exemplum, Megarios ab Atheniensibus, cum de Salamine contenderent, victos Homeri versu [...] ponitur a quibusdam et quidem in parte prima deorum auctoritas, quae est ex responsis, ut, Socraten esse sapientissimum. Id rarum est, non sine usu tamen. Utitur eo Cicero in libro de aruspicum responsis $[\ldots]$

2 Ibid.

3 Plethon reintroduced Platonic and Neoplatonic philosophy to the West, especially in Florence in the circles established by Cosimo de Medici, which were attended by Ficino. Woodhouse, George Gemistos Plethon, 373.

4 Introduction in Ficino, Sobre el Furor Divino y Otros Textos, xxi.

5 Kristeller, Ocho Filósofos del Renacimiento, 59.

6 Woodhouse, George Gemistos Plethon, 373; Celenza, "Marsilio Ficino"; however, one must understand the several meanings that the word "academia" can have; Hankins, "The Myth of the Platonic Academy of Florence," 433-36. 
As for reflexions drawn from the poets, not only speeches, but even works of the philosophers, are full of them; for although the philosophers think everything inferior to their own precepts and writings, they have not thought it beneath their dignity to quote numbers of lines from the poets to lend authority to their statements. Again, a remarkable example of the weight carried by authority is provided by the fact that when the Megarians disputed the possession of Salamis with the Athenians, the latter prevailed by citing a line from Homer [...] Some include under this head the supernatural authority that is derived from oracles, as for instance the response asserting that Socrates was the wisest of mankind: indeed, they rank it above all other authorities. Such authority is rare, but may prove useful. It is employed by Cicero in his speech on the Replies of the Soothsayers [... $]^{7}$

According to Quintilian, quotations from philosophers, poets, and even texts of divine inspiration could be used to add auctoritas. Examples of this rhetorical device proposed by Quintilian to add auctoritas included both Homer and the oracles - that is, appropriate examples for a writer in the 1st century. However, humanists such as Ficino had a broader repertoire upon which they could draw, including Greek and Roman, and, in the same vein, Christian authors, as well as the Bible, which provided a link to the power and influence of the Church.

One should not ignore or diminish the importance of prefaces; as Gérard Genette mentions in his Palimpsests, these paratexts should be reconsidered as a genre, providing different information not only about the author, printer, editor, or benefactor, but also about the relations between the preface, the main text, and texts that influenced them. ${ }^{8}$

Genette explains that the paratext enjoys a relationship that is less explicit and more distant within the totality of the literary work, at least compared to the relationship which binds this totality and the text sensu stricto. ${ }^{9}$ Paratexts can include valuable information, from subtitles or prefaces to epigraphs and illustrations. In this vein, the paratext provides the text with a setting "and sometimes a commentary, official or not, which even the purists among readers, those least inclined to external erudition, cannot always disregard

Quint. Inst. 5.11.39-42. Quintilian suggests that these quotes could help someone gain a case by the power invested in those authorities. The English translation by Harold Edgeworth Butler for the Loeb Classical Library.

8 Genette, Palimpsests, 7-8.

9 Ibid, 3 . 
as easily as they would like and as they claim to do."10 Another important category used by Genette is hypertextuality, which establishes a clearer relation between two texts. The relation is determined "between the imitated text and the imitative one, a supplementary stage and a mediation that are not to be found in the simple or direct type of transformation."11 The imitated one is called the hypertext, while the imitative is the hypotext. This paper will use these three categories to explain the relations between Ficino's preface, the imitated texts, and the figure of auctoritas. In this sense, Ficino's preface sets the guidelines for his translation and for the rest of the humanists interested in the Corpus Hermeticum.

\section{DESCRIPTION AND ANALYSIS OF THE PREFACE}

Ficino completed his translation of the Corpus Hermeticum in 1463, but it was only published in 1471, and even then, the work appeared without his permission. ${ }^{12}$ Later, in 1532, Ficino's translation was printed again in Basel, this time including his translations of Iamblichus and Proclus. ${ }^{13}$ The Basel edition includes the preface, dedicated to Cosimo de Medici, and has a marginal note on the second page regarding the Egyptian god Theuth, which other versions render as "Tem." Ficino's preface describes how he received the Greek version of the text from a monk, Leonardo da Pistoia, who sent it from Macedonia. ${ }^{14}$

The preface dedicated to Cosimo is divided into three main parts. The first one contains a description of Hermes Trismegistus; the second a description of Ficino's theory of the prisca theologia or "the ancient theology," previously developed by Plethon; ${ }^{15}$ and the third is a description of the work's content and its relevance.

10

11

Ibid.

Ibid, 6 .

Campanelli, "Marsilio Ficino's portrait of Hermes Trismegistus and its afterlife," 53 .

This is the version used here; the quotes are indicated as Fol.

"At nuper ex Macedonia in Italiam advectus, diligentia Leonardi Pistorensis, docti probique monachi ad nos prouenit." Fol. 5.

The discussion about the origin of the ancient theology attached to Plethon is not without controversies. Some affirm that he was the source for Ficino; see Kristeller (Ocho Filósofos del Renacimiento, 59); for others, like Woodhouse, this is not that clear, since Plethon did not mention Trismegistus in his writings (Woodhouse, George Gemistos Plethon, 373). Hanegraaff makes a 
As is the case with many prefaces of the period, ${ }^{16}$ Ficino's preface provides vital information about the period, the patronage, and the reception of the text. However, what is specific for his case is the figure of Hermes Trismegistus, which reflects the transmission of knowledge from antiquity. Ficino attempts to situate Hermes within both the Christian and the Greco-Roman traditions. He cites Augustine, Lactantius, and Cicero as authorities in support of his theory: "This was written of him by Aurelius Augustinus, although Cicero and Lactantius, believed there to be five consecutive Mercuriuses, the fifth being this one, who was called by the Egyptians < Theuth (in other Them)>, and by the Greeks, Trismegistus." ${ }^{17}$

In previous accounts, Trismegistus was a pagan figure related to astrology, alchemy, and during the Middle Ages, to magic. ${ }^{18}$ Ficino likely sought to change this conception of the Trismegistus figure by using the auctoritas given by citations from Augustine and Lactan-

good point about Ficino's role in developing of the prisca theologia, explaining he acted as a divine messenger (Hanegraaff and Pijnenburg, Hermes in the Academy, 7-8). Nevertheless, one cannot ignore the importance of the syncretism characterizing the prisca theologia and other trends during the fifteenth century, as well as its importance for the development of Hermeticism and other esoteric trends; see Szönyi, “The Hermetic Revival," 52-55.

On the importance of other prefaces of different authors see Villalba Álvarez,

"Un Interesante Capítulo En La Historia Del Libro: Los Prefacios de Aldo

Manucio a Sus Ediciones de Textos Griegos y Latinos."

"Hoc autem de illo scribit Augustinus: quanquam Cicero atque Lactantius,

Mercurios quinquem per ordinem fuisse volunt: quintumque fuisse illum, qui ab Aegyptiis Theuth, a Graecis autem Trismegistus appellatus est.” Fol. 3. The translation was published by Ilana Klutsein in Ficino's Hermetic Translation of His Latin Pimander and is used here with slight modifications.

18 During the Middle Ages and particularly in the western part of Europe, the figure of Hermes Trismegistus was related to astrology and magic. For example, there are several mentions in the Picatrix, a book about talismanic magic and astrology, in which Trismegistus is described, among his other skills, as an expert in astrology and divination; see Greer and Warnock, Picatrix, 133. The relation of Trismegistus with alchemy in Liber de compositione alchimiae, is described by Campanelli, "Marsilio Ficino's portrait of Hermes Trismegistus and its afterlife," 53-54. Lynn Thorndike presents the same argument. He proposes that Liber de compositione introduced the figure of Hermes Trismegistus as the father of alchemy in the 12th century. Thorndike argues that many alchemical texts used Hermes' auctoritas and authorship to gain recognition and acceptance, for example, A Treatise of Mercury to his disciple Mirnesin$d u s$ or The Secret of Hermes the philosopher, inventor of metals, according to the nature of transmutation; see Thorndike, History of Magic and Experimental 
tius. ${ }^{19}$ By using auctoritas, Ficino likely sought to change the perception of his arguments; it is no longer the opinion given by a single philosopher or translator, but consonant with the views expressed by those wise men that had set the pillars for the Christian Church against the ideas of the pagans. Maurizio Campanelli noticed, for example, how Ficino had changed a verb so that the text could conform more closely to the arguments expressed in the preface. ${ }^{2 \circ} \mathrm{He}$ had used the verb dubito to diminish the perception, expressed by Augustine, that Trismegistus was under some demonic influence. Ficino reconciled the opinion expressed by Augustine with that of Lactantius, who did not express doubt as Augustine did, and portrayed Trismegistus as the founder of the prisca theologia, granted by the Divine Mind, and as a figure akin to the prophets: "So that Aurelius Augustinus, as it happens, < pondered $>$ that he had foretold many things by divination of the stars or by demonic revelation. But Lactantius does not hesitate to count him among the Sibyls and the prophets." ${ }^{21}$

The figure of Hermes, however, was complicated even in antiquity. Herein lies the importance of Cicero's auctoritas, since he was the one who proposed the first rational explanation for Trismegistus. In De Natura Deorum, Cicero explains that there were five Hermeses, the first being a celestial god, while the fifth one is identified as Theuth by the Egyptians. ${ }^{22}$ This explanation served as a hypotext for both Christian authors; Augustine used it in De Civitate Dei ${ }^{23}$ and Lactantius in the Institutiones Divinae. ${ }^{24}$ The three texts served as the historical basis for the development proposed by Ficino. In other words, they were the hypotexts for Ficino's hypertext. These hypotexts had a significance that surpassed mere sources for quotations. References to them appear in the exordium, the beginning of the text, where Ficino shows not only the main idea of what he

Magic 2:214-18. In Thorndike's words: "among the Arabs and in medieval Latin learning the reputation of Hermes continued not only as an alchemist but as a fountain of wisdom in general"; ibid., 2:219.

Campanelli, "Marsilio Ficino's portrait of Hermes Trismegistus and its afterlife," 58 .

20 Campanelli, 57.

21 "Quo factum est, ut Aurelius Agusutinus dubitaverit, peritia ne syderum, an revelatione daemonum multa protulerit. Lactantius autem illum inter sibyllas ac prophetas connumerare non dubitas." Fol. 5.

22 Cic., Nat. D. 3.56.

23 Aug., De civ. D. 8.26.

24 Lact., Div. Inst. 1.6. 
will explain but also his abilities. He portrays himself as one of the literati, one who had read the authors of antiquity. By beginning with these texts, Ficino satisfies two goals. First, he fends off critiques of other intellectuals, since attacking Ficino would implicitly mean attacking Augustine's or Lactantius' opinions. Secondly, Ficino shows himself as a peritus, skilled in theological matters, that is, a person able to discuss and propose theories related to divine things, as the prisca theologia.

A different case of auctoritas is presented in the context of the prisca theologia itself, where the authority lies not in quotations but in the renown of the philosophers, listed from Hermes Trismegistus up to Plato. Among other things, the prisca theologia addressed this: "He was the first to debate with utmost wisdom the majesty of God, the rank of demons, and the mutations of souls. He was therefore called the first theologian. And Orpheus followed him, taking second rank in ancient theology." ${ }^{25}$ Ficino claims that this ancient theology was introduced in the books of Trismegistus, thus making him the author of all theology. But Ficino also asserts that Trismegistus "foresaw the ruin of the ancient religion (prisca theologia), the birth of the new faith, the advent of Christ, the future judgment, the resurrection of man, the renewal of the world, the glory of the blessed, and the torment of the sinners. ${ }^{26}$ Accordingly, Trismegistus appears as a prophet, not as a Biblical one but a pagan one, who was charged with spreading the word of God through philosophy, which eventually arrived at the Greeks.

Several biblical passages address the importance of tradition and the lines of succession. Examples are the priestly lineage inherited by Aaron and his sons from Moses' power by virtue of their descent from Levi, ${ }^{27}$ or the verification of the lineage of Jesus to prove that he was the Son of God. ${ }^{28}$ These examples demonstrate the authority of the characters, the idea that their ancestry allowed them to act above the rest of the population while their words and speeches were transformed into law. These lines of succession, as described in the Bible, were known to Ficino, who utilized the same technique for

"Primus de maiestate dei, daemonum ordine, animarum mutationibus sapientissime disputavit. Primus igitur theologiae appellatus est autor.” Fol. 4. tum Christi, hic futurum judicium, resurrecciones seculi, beatorum gloriam, supplicia peccatorum.” Fol. 5 . 
the Greek and pagan philosophers. Following Plethon, ${ }^{29}$ he acknowledged the pagan line of succession, especially the role of the Greeks, therein fashioning them as heirs of the word of God.

The line of succession proposed by Ficino in the preface of the Corpus Hermeticum begins with Hermes Trismegistus, the author of these dialogues and the one to whom the nature of God and of the temporal and eternal world, as well as the power and wisdom of God were revealed. ${ }^{30}$ Trismegistus is thus portrayed as the first theologian, one whose message was initially delivered in "Egyptian letters," and later via the Greek translation. Ficino, following Plethon, used the auctoritas of the theologians mentioned in the prisca theologia to explain the transmission of the ancient religion from one generation to the next. This ostensible line of succession continued through Orpheus, Pythagoras, Aglaophemus, and Philolaus before culminating with Plato as the last theologian. By enumerating these ancient philosophers, Ficino achieves two key ends: first, reconstructing a chronology for the transmission of the ancient theology; and then elevating them to the rank of pagan theologians who transmitted the word of God, even if they did so unaware.

Ficino's contention that the Christian and pagan lines of succession worked in parallel was consistent with his aim of reconciling the pagan and Christian frameworks. ${ }^{31}$ However, the selection of theologians is not without its problematic aspects since virtually no information is available for Aglaophemus, and not much is known of Philolaus, besides the fact that he came from Kroton.$^{32}$ For Orpheus, Pythagoras, and Plato, on the other hand, the preface manifests a clear interest to portray them in a less pagan light. Instead of that, Ficino portrays them as Greeks who had inherited wisdom from the Christian God via Trismegistus, which could reconcile them with the traditional opinion.

The pagan philosophers, portrayed by Ficino in this line of succession, became quasi-Christian prophets or, in the words of Ficino, theologians. This was meant to support their writings and help them

Moshe Idel points out Ficino's intention to put the Christian and pagan traditions on the same level and not, as sometimes suggested, one over the other, in the context of Gemistos Plethon; cf. Idel, "Prisca theologia in Marsilio Ficino" in Allen, Rees, and Davies, Marsilio Ficino, 147. Fol. 6.

31 Introduction of Carol V. Kaske and John R. Clark in Ficino, Three Books on Life, 38-39.

Diog. Laet., Vitae 3.6. 
become relevant literature for Christians. In this new scenario, the perception of these wise men from antiquity was transformed and mixed with the Christian mindset. Because of this syncretism, such an approach to these texts could not be interpreted as an attempt to resuscitate paganism but merely as a different approach to understanding the wisdom of God.

\section{CONCLUSION}

The authority displayed through this paratext does not remain static. Just as Genette explains, it offers a commentary of the main text, which is the translation of the first fourteen dialogues of the Corpus Hermeticum. At first glance, Cicero, Augustine, and Lactantius appear to serve as representative authorities for Ficino, the first for pagan antiquity, the other two for Christianity. However, a higher rank is attributed to Hermes Trismegistus because he, like the prophets of the Bible, received from the Divine Mind the revelation of God. According to this interpretation, while Moses was a prophet for the Jews, Trismegistus became the prophet for the gentiles. In this setting, both of them served in the same position. Ficino's rhetorical devices in the preface show his ability to manipulate the hierarchy of authority. He transformed Trismegistus into a theological authority by the use of the auctoritas provided by the other figures. The preface does more than merely invite the reader to approach the text or clarify some obscure terms. It presents Ficino as a translator, introducing the Corpus Hermeticum into humanist circles, ready to influence the reading of all those in search of God's wisdom. 


\section{BIBLIOGRAPHY}

Allen, Michael J. B., Valery Rees, and Martin Davies, eds. Marsilio Ficino: His Theology, His Philosophy, His Legacy. Leiden: Brill, 2002.

Campanelli, Maurizio. "Marsilio Ficino's Portrait of Hermes Trismegistus and Its Afterlife." Intellectual History Review 29.1 (2019): 53-71.

Celenza, Christopher S. "Marsilio Ficino.” Edited by Zalta. The Stanford Encyclopedia of Philosophy, 2011. Available online. Corsi, Giovanni. "The Life of Marsilio Ficino." In The Letters of Marsilio Ficino, translated by Language Department of the School of Economic Science, Vol. 3. London: Fellowship of the School of Economic Science, 1981.

Ficino, Marsilio, trans. Mercurii Trismegisti Pymander, de potestate et sapientia Dei: Eiusdem Asclepius, de voluntate Dei; Iamblichus de mysterijs Aegyptiorum, Chaldaeorum, \& Assyriorum; Proclus in Platonicum Alcibiadem, de anima \& daemone; idem de sacrificio \& magia. Basiliae, 1532.

- Sobre el Furor Divino y Otros Textos. Translated by Juan Maluquer and Jaime Sanz. Barcelona: Anthropos, 1993.

_. Three Books on Life. Translated by Carol V. Kaske and John R. Clark. Tempe: Renaissance Society of America, 1998.

Genette, Gérard. Palimpsests: Literature in the Second Degree. Lincoln: University of Nebraska Press, 1997.

Greer, John Michael, and Christopher Warnock, trans. Picatrix: The Classic Medieval Handbook of Astrological Magic. Iowa City: Adocentyn Press, 2011.

Hanegraaff, Wouter J., and Joyce Pijnenburg, eds. Hermes in the Academy: Ten Years' Study of Western Esotericism at the University of Amsterdam. Amsterdam: Amsterdam University Press, 2009.

Hankins, James. "The Myth of the Platonic Academy of Florence." Renaissance Quarterly 44.3 (1991): 429-75.

Klutstein, Ilana. "Ficino's Hermetic Translations: English Translation of His Latin Pimander." Available online.

Kristeller, Paul Oskar. Ocho Filósofos del Renacimiento. Translated by María Martinez Peñaloza. México: Fondo de Cultura Económica, 1985 .

Szönyi, György. “The Hermetic Revival.” In The Occult World, edited by Christopher Partridge, 51-73. London: Routledge, 2016. 
Thorndike, Lynn. A History of Magic and Experimental Science: During the First Thirteen Centuries of Our Era. Vol. II. New York: Columbia University Press, 1923.

Villalba Álvarez, Joaquín. "Un Interesante Capítulo En La Historia Del Libro: Los Prefacios de Aldo Manucio a Sus Ediciones de Textos Griegos y Latinos." Talia Dixit 12 (2017): 87-103.

Woodhouse, C. M. George Gemistos Plethon: The Last of the Hellenes. Oxford: Clarendon Press, 2000. 


\section{ABSTRACT}

Marsilio Ficino's fame as a translator, not least due to his contributions to theology and the development of hermeticism, has already been established by Frances Yates and debated by Wouter Hanegraaff. For each of his translations of Greek texts, Ficino wrote a preface to guide and to manipulate the reader. This paper presents an analysis of the auctoritas in the paratext of the Corpus Hermeticum, analyzing it as a rhetorical device used by Ficino to express his ideas, particularly the role of Hermes Trismegistus. Ficino used his rhetorical skill not only to translate from Greek to Latin but also to support his theories in commentaries, letters, or, in this case, prefaces.

\section{KEYWORDS}

hypertext, auctoritas, Marsilio Ficino, Hermes Trismegistus, preface 


\section{IZVLEČEK}

Klasična in krščanska auctoritas

v predgovoru Marsilia Ficina za Corpus hermeticum

Sloves Marsilia Ficina kot prevajalca, nenazadnje tudi na podlagi njegovih prispevkov $\mathrm{k}$ teologiji in razvoju hermetizma, je izpostavila že Frances Yates, o njem pa je razpravljal denimo Wouter Hanegraaff. K vsakemu od svojih prevodov grških besedil je Ficino napisal predgovor, ki naj bi bralca vodil in nanj vplival. Prispevek analizira auctoritas v paratekstu, ki spremlja Corpus Hermeticum, ter jo analizira kot retorični pripomoček, s katerim Ficino izrazi svoje ideje - zlasti o vlogi Hermesa Trismegista. Ficino svoje retorične veščine ni uporabljal samo za prevajanje iz grščine v latinščino, temveč tudi za podpiranje lastnih teorij v komentarjih, pismih ali - kot $\mathrm{v}$ tem konkretnem primeru - v predgovorih.

\section{KLJUČNE BESEDE}

hipertekst, auctoritas, Marsilio Ficino, Hermes Trismegist, predgovor 